\title{
Nitrogen and in vitro Fermentation of Nitrogenous Substrates in Caecal Contents of the Pig
}

\author{
M. MAROUNEK ${ }^{1,2}$, T. ADAMEC ${ }^{2}$, V. SKŘIVANOVÁ², N.I. LATSIK ${ }^{3}$ \\ 1 Institute of Animal Physiology and Genetics, Czech Academy of Sciences, Prague, Czech Republic \\ 2 Research Institute of Animal Production, Prague, Czech Republic \\ 3 Institute of Biotechnology, Lvov State Academy of Veterinary Medicine, Lvov, Ukraine
}

Received July 9, 2002

Accepted November 18, 2002

Abstract

Marounek M., T. Adamec, V. Skřivanová, N.I. Latsik: Fractions of Nitrogen and in vitro Fermentation of Nitrogenous Substrates in Caecal Contents of the Pig. Acta Vet. Brno 2002, 71: 429-433.

Caecal contents of four 28-week-old pigs were analysed and used as inocula of cultures supplied with plant proteins (gluten, gliadin, zein), mucin, ribonucleic acid (RNA) and glucose. Pigs were fed ad libitum a $14.1 \%$ crude protein diet containing barley, wheat, wheat bran, extracted soybean meal and a feed supplement. The caecal digesta contained dry matter, total $\mathrm{N}$, protein, trichloroacetic acid (TCA)-soluble N and NH3-N at 120, 3.1, 14.9, 0.64 and 0.27 $\mathrm{mg} / \mathrm{g}$ (on average), respectively. One $\mathrm{g}$ of the caecal content contained $70 \mu \mathrm{mol}$ of glycine equivalents of amino acids in TCA-soluble fraction. Peptides rather than amino acids were the primary component of the TCA-soluble ninhydrin-reactive material in the caecum.

Fermentation of mucin yielded more volatile fatty acids (VFA) than fermentation of other nitrogenous substrates. Zein was the least fermentable substrate tested. Acetate was the principal fermentation end-product, followed by propionate and butyrate. Fermentation pattern differed in cultures grown on glucose and proteins: propionate molar proportions were higher and those of branched-chain VFA lower in former cultures than in cultures supplied with gluten, gliadin and zein. Low proportions of branched-chain VFA were also in VFA produced from mucin and RNA. It can be concluded, therefore, that caecal microorganisms convert nitrogenous substrates, which would be lost in faeces, into valuable products (VFA), utilizable by the host.

Pig, caecum, nitrogenous substances, protein, fermentation, in vitro, microbial metabolites

In pigs, most nutrients are released from the feed by action of endogenous enzymes, and absorbed in the small intestine. In the lower ileum, caecum and colon, an intensive microbial degradation of available nutrients takes place. A significant portion of the digestible energy thus could be ingested post-ileally, depending on the composition of pig the diet . In growing pigs, the hindgut fermentation contributed up to $15 \%$ to the total digestion of the organic matter, whereas this level can reach $50 \%$ in sows (reviewed by Drochner 1993). Microorganisms in the hindgut convert polysaccharides and nitrogenous substances into a mixture of metabolites and compounds of bacterial cells. Nitrogenous substances entering the hindgut are undegraded dietary proteins, i.e. plant proteins of low solubility (prolamins and glutelins), and proteins of endogenous origin, i.e. enzymes and mucin secretions, and cell desquamation products. Ileal solids contained 16.1 and $20.2 \%$ of crude protein $(\mathrm{N}$ x 6.25) in pigs on a high-fibre diet with wheat bran, and on a low-fibre diet, respectively (Knudsen and Canibe 2000). Additional $\mathrm{N}$ sources in the hindgut are proteins and nucleic acids released from lysed bacterial cells. As shown by Dierick et al. (1990), the bacterial growth efficiency in pig hindgut is rather low: on average $13.6 \mathrm{~g}$ bacterial $\mathrm{N}$ was excreted in the faeces per $\mathrm{kg}$ of organic matter apparently digested in the hindgut. Corresponding values in the rumen

Address for correspondence:

Prof. Ing. M. Marounek, DrSc.

Institute of Animal Physiology and Genetics

Př́telství 560, Prague 10-Uhř́něves, CZ-104 00 Czech Republic
Phone: +420267009616

Fax: +420267090500

http://www.vfu.cz/acta-vet/actavet.htm 
vary around a mean of $\mathrm{ca} 30 \mathrm{~g} \mathrm{~N}$ per $\mathrm{kg}$ of organic matter apparently digested (Demeyer and Van Nevel 1986). A more extensive lysis of bacterial cells in the pig hindgut is a possible explanation of this difference.

As shown by Drochner (1984), the capability of pigs to digest dietary fibre is considerable if adequate $\mathrm{N}$ is supplied to the hindgut microflora. Whereas carbohydrate metabolism in the pig hindgut has been investigated in many studies, knowledge on fermentation of nitrogenous substrates in pigs is far from complete. The present study was carried out $(i)$ to determine the amount of the total and trichloroacetic acid (TCA)-soluble nitrogen, protein, ammonia and amino acids in the caecal digesta of ad libitum fed pigs, and (ii) to examine fermentation pattern in cultures of the caecal contents supplied with plant proteins, mucin and nucleic acids. For comparison, the fermentation in caecal cultures with glucose was also investigated.

\section{Materials and Methods}

Pigs

Castrated male pigs (Czech White) were fed ad libitum a standard diet containing barley (39\%), wheat (29\%), wheat bran (20\%), extracted soybean meal (9\%) and a feed supplement MastSan (SANO). The diet contained $14.1 \%$ of crude protein, $4.5 \%$ of fibre and metabolizable energy at $12.3 \mathrm{MJ} / \mathrm{kg}$. Four pigs were slaughtered at the age of 28 weeks (average live weight of $106 \mathrm{~kg}$ ), their caeca emptied, pooled, mixed and used for incubation of in vitro cultures. Individual samples of digesta were taken for analyses.

Analyses of caecal contents

The $\mathrm{pH}$ of the digesta was measured immediately after sampling. Dry matter (DM) of the caecal contents was determined by drying at $105^{\circ} \mathrm{C}$ overnight. Total nitrogen $(\mathrm{N})$ was determined using the Kjeltec Auto 1030 Analyser (Tecator AB, Sweden). To determine TCA-soluble N, ammonia and amino acids in TCA-supernatant, caecal contents $(20 \mathrm{~g})$ were mixed with $7 \%(\mathrm{w} / \mathrm{v})$ trichloroacetic acid $(60 \mathrm{ml})$. The mixture was refrigerated overnight, then centrifuged at $8000 \mathrm{~g}$ for $20 \mathrm{~min}$. TCA-soluble $\mathrm{N}$ was determined in the supernatant by the Kjeldahl procedure, and ammonia colorimetrically with Nessler reagent, after prior separation from interfering compounds by microdiffusion in Conway units. TCA-precipitate was washed with $7 \%$ trichloroacetic acid and protein extracted with $1 \mathrm{M} \mathrm{NaOH}$ at $100{ }^{\circ} \mathrm{C}$ for $1 \mathrm{~h}$. Extracted protein was determined by the Lowry method (Herbert et al. 1971). Free amino acids in the TCA-supernatant were detected by the ninhydrin reagent containing ninhydrin $(1 \mathrm{~g})$, hydrindantin $(50 \mathrm{mg})$, methylcellosolve $(38 \mathrm{ml})$ and acetate buffer $(12.6 \mathrm{ml})$. The method was calibrated with glycine. A portion of the TCA-supernatant was mixed $1: 1$ with $12 \mathrm{M} \mathrm{HCl}$ and heated at $110{ }^{\circ} \mathrm{C}$ for $22 \mathrm{~h}$. The hydrolysate was neutralized and free amino acids assayed using the same procedure. Volatile fatty acids were determined in samples of caecal contents diluted with physiological saline $1: 3$ by titration, after steam distillation. Lactic acid in these samples was determined by a microdiffusion method (Conway 1957).

Incubation

Incubations were carried out in triplicate on a shaking water bath at $39{ }^{\circ} \mathrm{C}$, in $300 \mathrm{ml}$ bottles. The caecal contents (25 g) were added to $75 \mathrm{ml}$ of the McDougall buffer (McDougall 1949) containing microelements and vitamins. Substrates were added at $1 \mathrm{~g}$ per incubation. Gluten from wheat and zein from maize were purchased from Sigma. Lipids from gluten were removed by diethylether extraction. Gliadin from wheat and mucin from pig stomach were bought from Fluka. Sodium ribonucleate (RNA) from yeast was supplied by ICN. The sixth substrate was glucose (a positive control). Sodium sulphide was added to the incubation fluid at 0.5 $\mathrm{g} / \mathrm{l}$ as a reducing agent. Bottles were thoroughly flushed with $\mathrm{CO}_{2}$, closed with rubber stoppers and incubated for $19 \mathrm{~h}$. Blank incubations were carried out by incubating diluted caecal contents without substrate.

Analyses of incubation fluid and gas

The VFA concentrations were determined by titration, after steam distillation in the Markham apparatus. Molar percentages of acetate (C2), propionate (C3), isobutyrate (iC4) butyrate (C4), isovalerate (iC5) and valerate (C5) were estimated on a gas chromatograph with a FI detector, equipped with a column of the Chromosorb WAW with 15\% SP 1200 and 1\% H3PO4 (Supelco). The separation was carried out at $140{ }^{\circ} \mathrm{C}$. Lactate was assayed as described above. Samples of the headspace gas were taken at the end of the incubation and analysed with the gas chromatograph, using the same column operated at room temperature. Production of metabolites from substrates tested was calculated by correcting findings for amounts present in incubated blanks.

The analysis of variance and Bonferroni test were used to evaluate differences in VFA production. Hydrogen recovery in cultures supplied with glucose was calculated according to Marty and Demeyer (1973). 


\section{Results and Discussion}

Concentrations of DM, VFA, lactic acid and $\mathrm{pH}$ values of the caecal contents were more or less stable, only limited animal variation was observed. Data presented in Table 1 do not differ much from our previous findings in pigs fasted for $16 \mathrm{~h}$ before slaughter (Marounek et al. 1997). Crude protein (calculated using the factor 6.25) and true protein (determined by the Lowry method) represented 16.1 and $12.4 \%$ of digesta DM, respectively (Table 2).

Table 1

Contents of dry matter (DM), volatile fatty acids (VFA), lactic acid and $\mathrm{pH}$ values of the caecal digesta of pigs.

\begin{tabular}{|l|c|c|}
\hline & Per g of digesta & Per g of digesta DM \\
\hline Dry matter $(\mathrm{g})$ & $0.120 \pm 0.008$ & 1.000 \\
\hline VFA $(\mu \mathrm{mol})$ & $156.3 \pm 14.4$ & $1302 \pm 120$ \\
\hline Lactic acid $(\mu \mathrm{mol})$ & $2.19 \pm 0.25$ & $18.3 \pm 2.1$ \\
\hline $\mathrm{pH}$ & \multicolumn{2}{|c|}{$6.03 \pm 0.22$} \\
\hline
\end{tabular}

Mean values and standard deviations. Caecal contents of 4 pigs were analyzed.

Table 2

Contents of total nitrogen $(\mathrm{N})$, protein, trichloroacetic acid (TCA)-soluble $\mathrm{N}$, ammonia and amino acids in the caecal digesta of pigs

\begin{tabular}{|l|c|c|}
\hline & Per g of digesta & Per g of digesta DM \\
\hline Total N (mg) & $3.10 \pm 0.28$ & $25.83 \pm 1.84$ \\
\hline Protein $(\mathrm{mg})$ & $14.91 \pm 1.87$ & $124.25 \pm 21.6$ \\
\hline TCA-soluble $N$ & & $5.33 \pm 0.04$ \\
\hline Total $(\mathrm{mg})$ & $0.64 \pm 0.04$ & $2.25 \pm 0.02$ \\
\hline NH3-N (mg) & $0.27 \pm 0.02$ & \\
\hline Amino acids in TCA-supernatant* & & $0.125 \pm 0.009$ \\
\hline Before hydrolysis (mmol/l) & $0.015 \pm 0.001$ & $0.583 \pm 0.021$ \\
\hline After hydrolysis (mmol/l) & $0.070 \pm 0.006$ & \\
\hline
\end{tabular}

Mean values and standard deviations. Caecal contents of 4 pigs were analyzed.

* Ninhydrin-reactive compounds expressed as glycine equivalents

Corresponding values found in the rabbit caecal contents were 27.6 and $18.2 \%$ DM (Marounek et al. 2000). The main fraction of crude protein in the pig caecum, thus, was the true protein. True protein accounted for three-quarters, and TCA-soluble nitrogenous substances for $20.6 \%$ of the total $\mathrm{N}$ in the caecal digesta. Ammonia $\mathrm{N}$ represented $42.2 \%$ of TCA-soluble N. Caecal contents contained $15 \mu \mathrm{mol}$ of glycine equivalents of TCA-soluble amino acids per $1 \mathrm{~g}$. Acid hydrolysis increased this amount to $70 \mu \mathrm{mol} / \mathrm{g}$. This indicates that low-molecular-weight peptides were the primary component of the TCA-soluble ninhydrinreactive material in the caecum. Similarly, also in the rumen (Chen et al. 1987), and in the rabbit caecum (Marounek et al. 2000), peptides rather than amino acids were the principal source of non-protein non-ammonia $\mathrm{N}$.

Proteins tested and RNA differed in their fermentability. Fermentation of mucin yielded significantly more VFA than fermentation of other nitrogenous substrates (Table 3 ). Mucin is a glycoprotein, present in saliva, gastric juice and intestinal juice. Pig gastric mucin contains $77 \%$ of carbohydrates and $21 \%$ of protein (Hill 1986). Holmes et al. (1974) were probably the first authors who reported that in pigs large amounts of mucin were fermented in the large intestine. Zein was the poorest substrate out of the five nitrogen compounds tested. Zein is a very hydrophobic protein, the principal protein of maize. Acetate was the principal fermentation end-product in all incubations, followed by propionate and butyrate. 
Table 3

Effect of substrate on production* and molar proportions of volatile fatty acids (VFA), lactate and methane in cultures of pig caecal contents supplied with proteins, ribonucleic acid (RNA) and glucose

\begin{tabular}{|c|c|c|c|c|c|c|c|c|c|}
\hline \multirow{2}{*}{ Substrate } & \multirow{2}{*}{$\begin{array}{c}\text { Total VFA } \\
(\mathrm{mmol} / \mathrm{l})\end{array}$} & \multicolumn{6}{|c|}{ Molar percentages } & \multirow{2}{*}{$\begin{array}{c}\text { Lactate } \\
(\mathrm{mmol} / \mathrm{l})\end{array}$} & \multirow{2}{*}{$\begin{array}{l}\text { Methane } \\
(\mathrm{mmol} / \mathrm{l})\end{array}$} \\
\hline & & $\mathrm{C} 2$ & $\mathrm{C} 3$ & iC4 & $\mathrm{C} 4$ & iC5 & $\mathrm{C} 5$ & & \\
\hline \multirow{2}{*}{ Gluten } & $46.1 \mathrm{a}$ & 41.2 & 29.6 & 2.3 & 10.9 & 5.4 & 10.6 & 0.05 & 1.11 \\
\hline & $(5.8)$ & (1.9) & $(4.7)$ & $(0.9)$ & (2.2) & $(0.8)$ & $(0.6)$ & $(0.05)$ & $(0.15)$ \\
\hline \multirow{2}{*}{ Gliadin } & $24.5 b$ & 46.5 & 21.5 & 3.0 & 11.1 & 6.5 & 11.4 & \multirow{2}{*}{0} & 0.89 \\
\hline & (3.1) & $(0.4)$ & $(0.1)$ & $(0.2)$ & (1.8) & $(0.3)$ & $(0.7)$ & & $(0.12)$ \\
\hline \multirow{2}{*}{ Zein } & $12.5 b$ & 50.9 & 18.0 & 2.3 & 14.0 & 9.3 & 5.5 & \multirow{2}{*}{0} & 0.83 \\
\hline & $(3.3)$ & (19.8) & (10.6) & $(0.7)$ & (6.0) & (2.5) & (1.5) & & $(0.48)$ \\
\hline \multirow{2}{*}{ Mucin } & $114.2 \mathrm{c}$ & 55.7 & 28.5 & 1.0 & 9.3 & 0.8 & 4.7 & \multirow{2}{*}{0} & 1.19 \\
\hline & (3.7) & $(0.8)$ & (1.0) & $(0.1)$ & $(0.2)$ & $(0.2)$ & (1.6) & & $(0.10)$ \\
\hline \multirow[b]{2}{*}{ RNA } & $48.6 a$ & 58.0 & 32.4 & 0.5 & 8.7 & & 0.4 & \multirow[b]{2}{*}{0} & 0.76 \\
\hline & $(4.8)$ & (0.9) & (1.4) & $(0.1)$ & $(0.4)$ & 0 & $(0.1)$ & & $(0.42)$ \\
\hline \multirow{2}{*}{ Glucose } & $96.6 \mathrm{~d}$ & 48.9 & 41.7 & 0.1 & 8.8 & 0.1 & 0.4 & 0.10 & 1.12 \\
\hline & $(3.1)$ & $(0.7)$ & $(0.4)$ & $(0.1)$ & $(0.4)$ & $(0.0)$ & $(0.1)$ & $(0.05)$ & $(0.15)$ \\
\hline
\end{tabular}

Means of 3 cultures. Standard deviations are given in parentheses.

* Data were corrected for amounts present in incubated blanks.

a-d Values with different superscripts differ significantly $(P<0.05)$.

Fermentation pattern differed in cultures supplied with glucose and proteins. Propionate molar proportion was higher and proportions of branched-chain VFA lower in former cultures. Molar proportions of branched-chain VFA were also lower in cultures supplied with mucin and RNA, i.e. supplied with substrates containing a carbohydrate moiety. Both lactate and methane productions were low. Low value of metabolic hydrogen recovery $(61.0 \%$ in glucose-grown cultures, on average) indicated the presence of reductive acetogenesis, which is an alternative electron sink to methanogenesis.

In pigs, the disapperance of total $\mathrm{N}$ between ileum and rectum represents about $10 \%$ of the total $\mathrm{N}$ intake. Holmes et al. (1974) found that in growing pigs fed diets containing soyabean meal and rapeseed meal 8.0 and $12.4 \%$ of the total $\mathrm{N}$ intake, respectively, was digested in the hindgut. The nutritional significance of the hindgut nitrogen metabolism is inevitably reduced by the fact that neither bacterial protein nor non-volatile products of catabolism of nitrogenous substrates were utilized by the host. Thus, as it has been emphasized by Dierick et al. (1990), a low bacterial growth efficiency combined with a large VFA production is preferred in this digestive segment. Hindgut microbes convert macromolecular nitrogenous substances, which would be lost in faeces, into VFA, available to the host. Branched-chain VFA are growth factors for cellulolytic bacteria (Deh ority et al. 1967). In addition, ammonia released from $\mathrm{N}$-containing compounds during this process is the main source of nitrogen for fibrolytic microflora.

\section{Frakce dusíku a fermentace dusíkatých látek in vitro v obsahu slepého střeva prasat}

Analyzovali jsme obsahy slepých střev čtyř prasat poražených ve věku 28 týdnů. Tyto obsahy jsme současně použili jako inokula kultur v nichž substrátem byly rostlinné proteiny (gluten, gliadin, zein), mucin, ribonukleová kyselina (RNA) a glukosa. Prasata byla před porážkou krmena ad libitum dávkou s obsahem 14,1\% N-látek, složenou z ječmene, pšenice, otrub, extrahovaného sojového šrotu, s přídavkem krmného doplňku. Zažitina slepého střeva v $1 \mathrm{~g}$ obsahovala $\mathrm{v}$ průměru $120 \mathrm{mg}$ sušiny, 3,1 mg celkového $\mathrm{N}, 14,9 \mathrm{mg}$ proteinu, 
0,64 mg N rozpustného v 5,25\% kyselině trichloroctové (TCA) a 0,27 mg NH3-N. Dále bylo v $1 \mathrm{~g}$ zažitiny $70 \mu$ molů aminokyselin rozpustných v TCA (v přepočtu na glycin). Hlavní složkou této frakce nebyly volné aminokyseliny, ale nízkomolekulární peptidy.

V kulturách obsahu slepého střeva vznikalo nejvíce těkavých mastných kyselin (TMK) fermentací mucinu a nejméně fermentací zeinu. Hlavním fermentačním produktem byl acetát, následovaný propionátem a butyrátem. Stechiometrie fermentace $\mathrm{v}$ kulturách s glukosou a proteiny byla odlišná, nebot při fermentraci glukosy vznikalo více propionátu a méně TMK s rozvětveným řetězcem než při fermentaci glutenu, gliadinu a zeinu. Nízký podíl TMK s rozvětveným řetězcem byl nalezen také v kulturách s mucinem a RNA. Lze shrnout, že fermentací sloučenin dusíku v slepém stř̌evu prasat vznikají těkavé produkty využitelné hostitelem, z makromolekulárních látek, které by jinak byly ztraceny ve výkalech.

\section{Acknowledgement}

This study received financial support from the Ministry of Agriculture of the Czech Republic (project No. MO299-04).

\section{References}

CHEN, G, RUSSELL, JB, SNIFFEN, CJ 1987: A procedure for measuring peptides in rumen fluid and evidence that peptide uptake can be a rate-limiting step in ruminal protein degradation. J Dairy Sci 70: 1211-1219

CONWAY, EJ 1957: Microdiffussion Analysis and Volumetric Error. Crosby Lockwood and Son. London, pp. 248-278

DEHORITY, BA, SCOTT, HW, KOWALUK, P 1967: Volatile fatty acid requirements of cellulolytic rumen bacteria. J Bacteriol 94: 537-543

DEMEYER, DI, VAN NEVEL, C 1986: Influence of substrate and microbial interactions on efficiency of rumen microbial growth. Reprod Nutr Dev 26: 161-179

DIERICK, NA, VERVAEKE, IJ, DECUYPERE, JA, HENDERICKX, HK 1990: Bacterial protein synthesis in relation to organic matter digestion in the hindgut of growing pigs; contribution of hindgut fermentation to total energy supply and growth performances. J Anim Physiol a Anim Nutr 63: 220-235

DROCHNER, W 1984: The influence of changing amounts of crude fibre and pectin components on prececal and postileal digestive processes in the growing pigs. Adv Anim Physiol Anim Nutr 14: 125

DROCHNER, W 1993: Digestion of carbohydrates in the pig. Arch Anim Nutr 43: 95-116

HERBERT, D, PHIPPS, PJ, STRANGE, RE 1971: Chemical analysis of microbial cells. In: Norris, JR, Ribbons, DW: Methods in Microbiology. Academic Press, London, pp. 209-344

HILL, RRH 1986: Digestion of mucin polysaccharides in vitro by bacteria isolated from the rabbit cecum. Curr Microbiol 14: 117-120

HOLMES, JHG, BAYLEY, HS, LEADBEATER, PA 1974: Digestion of protein in small and large intestine of the pig. Br. J. Nutr. 32: 479-489

KNUDSEN, KEB, CANIBE, N 2000: Breakdown of plant carbohydrates in the digestive tract of pigs fed on wheator oat-based rolls. J Sci Food Agric 80: 1253-1261

MAROUNEK, M, SAVKA, OG, SKŘIVANOVÁ, V 1997: Effect of salinomycin on in vitro caecal fermentation in pigs. J Anim Physiol a Anim Nutr 77: 111-116

MAROUNEK, M, SKŘIVANOVÁ, V, DUŠKOVÁ, D 2000: In vitro caecal fermentation of nitrogenous substrates in rabbits. J Agr Sci, Camb 135: 437-442

MARTY, RJ, DEMEYER, DI 1973: The effect of inhibitors of methane production on fermentation pattern and stoichiometry in vitro using rumen contents from sheep given molasses. Br J Nutr 30: 369-376

MC DOUGALL, EI 1949: Studies on ruminant saliva. I. The composition and output of sheep's saliva. Biochem J 43: 99-106 